\section{SOI: $1.1 /$ TAS DOI: $10.15863 /$ TAS International Scientific Journal Theoretical \& Applied Science}

p-ISSN: 2308-4944 (print) e-ISSN: 2409-0085 (online)

Year: $2018 \quad$ Issue: 02 Volume: 58

Published: $26.02 .2018 \quad$ http://T-Science.org
M.Sc.Eng., Corresponding Member of International Academy of Theoretical and Applied Sciences, Lecturer of Vladimir Industrial College, Russian Federation chemezov-da@yandex.ru

SECTION 7. Mechanics and machine construction.

\title{
FEED SELECTION OF CUTTING TOOLS AT FINISHED MACHINING
}

Abstract: Feed values of turning, milling and axial cutting tools at finished machining of steel workpieces are recommended in the article. It is determined that the highest productivity of finished turning of the workpiece is achieved by using a round carbide insert. Mechanical clamped of throw-away (indexable) carbide inserts to a tool mount allows to increase of feed of the cutting tool up to 10 times compared to the one-piece cutting tool made from high-speed steel.

Key words: feed, a milling cutter, clamped, an indexable insert.

Language: English

Citation: Chemezov D (2018) FEED SELECTION OF CUTTING TOOLS AT FINISHED MACHINING. ISJ Theoretical \& Applied Science, 02 (58): 101-104.

Soi: http://s-o-i.org/1.1/TAS-02-58-21 Doi: crossef https://dx.doi.org/10.15863/TAS.2018.02.58.21

\section{Introduction}

Machining of metal workpieces allows to obtain different surfaces on a part with high accuracy. High accuracy of dimensions, shape and other parameters of the part are achieved at finished machining. Productivity of finished machining at observance of the technical requirements to manufacturing of the part can be possible to increase at a correct selection of a cutting tool (material and geometry of a cutting part of the tool, the tool rigidity and etc.). For setting of machining parameters it is possible to take into account material, roughness value and a diameter of the processed surface of the workpiece (the cutting tool). Based on the performed experiments and the results of mathematical calculations, it will be possible to make the conclusion about the choice of the rational cutting tool and setting of feed for performed turning, drilling and milling operations.

\section{Materials and methods}

Feed setting for the cutting tools at finished machining of structural steel $(<0.25 \%$ of carbon) was the goal of the research. Turning by cutters, milling and machining of cylindrical holes by the axial cutting tools were carried out.

For longitudinal turning of the steel workpieces with the outer diameter of $1-400 \mathrm{~mm}$, throw-away (indexable) inserts of round, rhombic and triangular shapes were used [1]. Cemented carbide was material of the throw-away (indexable) inserts. The inserts were clamped to a cutter holder by the mechanical method [2].
The one-piece and carbide-tipped milling cutters: end milling cutter, face milling cutter, radial milling cutter, T-slot milling cutter and conical milling cutter were used for milling of the workpieces [3; 4]. The one-piece milling cutters were made from high-speed steel. Milling cutters diameters varied in the range from 1 to $150 \mathrm{~mm}$ according to a type of the cutting tool.

The following axial tools: center and spiral drills, multiflute drill and reamer $[5 ; 6]$ were used for machining of the cylindrical holes in the workpieces. The highest diameter of the axial tools was adopted by $40 \mathrm{~mm}$. The multiflute drill and the reamer were made only from high-speed steel.

Machining was carried out on the serviceable technological equipment with minimal wear and tear [7;8]. Durability of the cutting tools was 30 minutes at presence of cutting fluid. The cutting tools had a medium length. The processed workpieces did not expose to heat treatment. A correction coefficient considered changing of cutting forces due to subjective factors was adopted by 1 .

\section{Results and discussion}

Machining of the workpieces was carried out at the same cutting parameters. The experiments results were processed mathematically and the dependencies graphs of feed value of the cutting tools from the diameter of the processed steel workpiece (the cutting tool) were constructed. The dependencies of feed of the carbide-tipped turning cutters from the workpiece diameter are presented in the Fig. 1. 


\begin{tabular}{|c|c|c|c|c|c|c|}
\hline Impact Factor: & $\begin{array}{l}\text { ISRA (India) } \\
\text { ISI (Dubai, UAE } \\
\text { GIF (Australia) } \\
\text { JIF }\end{array}$ & $\begin{array}{r}=1.344 \\
=0.829 \\
=0.564 \\
=1.500\end{array}$ & $\begin{array}{l}\text { SIS (USA) } \\
\text { PИHЦ (Russia) } \\
\text { ESJI (KZ) } \\
\text { SJIF (Morocco) }\end{array}$ & $\begin{array}{l}=0.912 \\
=0.207 \\
=4.102 \\
=2.031\end{array}$ & $\begin{array}{l}\text { ICV (Poland) } \\
\text { PIF (India) } \\
\text { IBI (India) }\end{array}$ & $\begin{array}{l}=6.630 \\
=1.940 \\
=4.260\end{array}$ \\
\hline
\end{tabular}

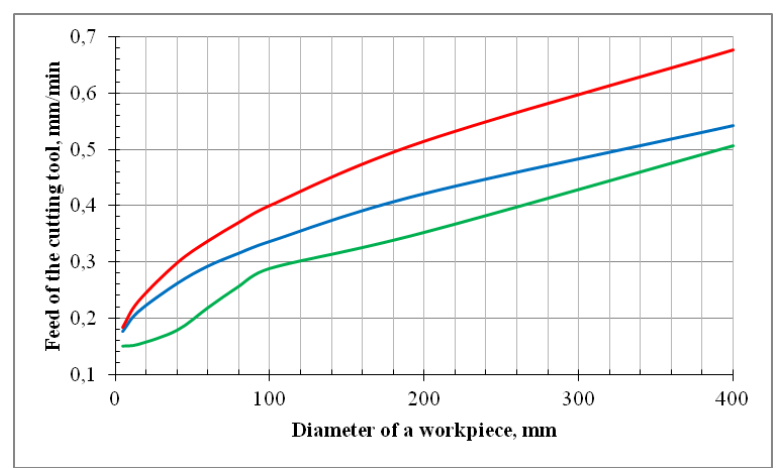

Figure 1 - The dependencies of feed of the turning cutters from the workpiece diameter: - the round carbide insert (mechanically clamped), — the rhombic carbide insert (mechanically clamped), — the triangular carbide insert (mechanically clamped).

The graph shows that finished turning by the round insert can be possible to perform at large feeds of the cutting tool. On every $100 \mathrm{~mm}$ of the workpiece diameter it is allowed increasing of feed of the cutting tool by $0.1 \mathrm{~mm} / \mathrm{min}$. The triangular insert has less strength, therefore it is necessary to reduce feed of the corresponding turning cutter. Recommended feeds at turning of the workpieces up

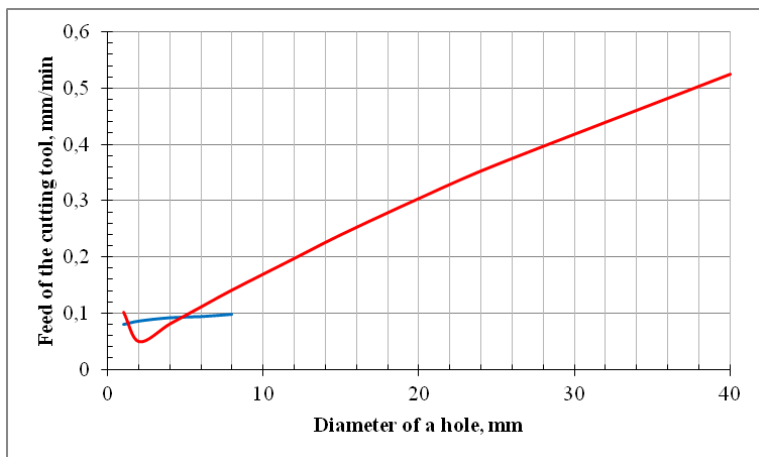

a) to $100 \mathrm{~mm}$ by the triangular insert are not more than $0.3 \mathrm{~mm} / \mathrm{min}$.

The dependencies of feed value from the diameter and material of the center and the spiral drills are presented in the Fig. 2. Comparising of feed value at machining of the holes by the multiflute drill and the reamer is presented in the Fig. 3.

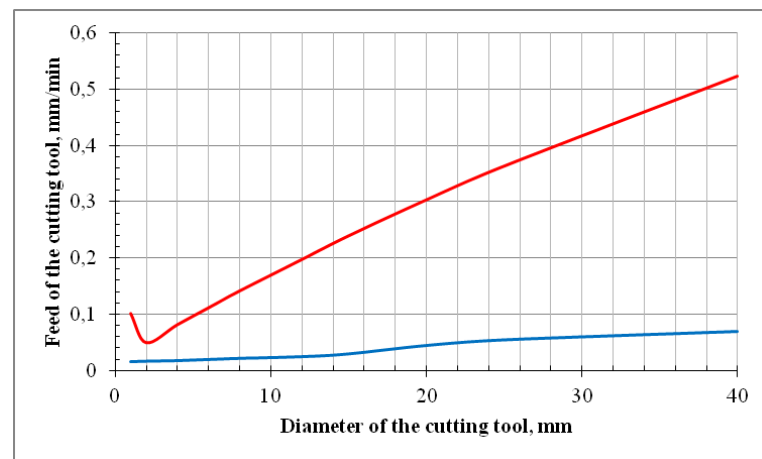

b)

Figure 2 - The dependencies of feed of the axial tools from their diameters: a) - the center drill made from high-speed steel (the one-piece tool), — the carbide-tipped center drill (mechanically clamped); b) — the spiral drill made from high-speed steel (the one-piece tool), — the carbide-tipped spiral drill (mechanically clamped).

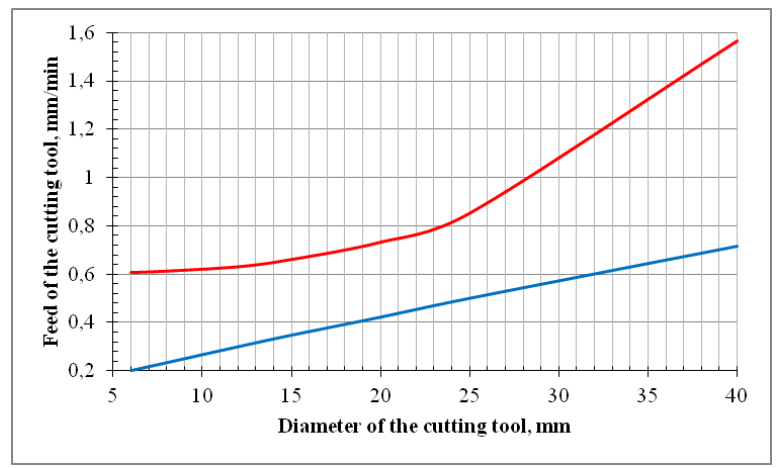

Figure 3 - The dependencies of feed of the axial tools from their diameters: - the cylindrical multiflute drill made from high-speed steel (the one-piece tool), — the cylindrical reamer made from high-speed steel (the one-piece tool). 


\begin{tabular}{|c|c|c|c|c|c|c|}
\hline \multirow{4}{*}{ Impact Factor: } & ISRA (India) & $=1.344$ & SIS (USA) & $=0.912$ & ICV (Poland) & $=6.630$ \\
\hline & ISI (Dubai, UAE & $=0.829$ & РИНЦ (Russia) & $=0.207$ & PIF (India) & $=1.940$ \\
\hline & GIF (Australia) & $=0.564$ & ESJI (KZ) & $=4.102$ & IBI (India) & $=4.260$ \\
\hline & JIF & $=1.500$ & SJIF (Morocco & $=2.031$ & & \\
\hline
\end{tabular}

Drilling of the holes with the diameter of $1-8$ mm was carried out by the center drill made from high-speed steel. At that feed of the center drill does not change. The process of the holes drilling in solid material is characterized by significant temperatures in the cutting zone and cutting forces. Taking into account these processing factors, feed of the spiral drill made from high-speed steel is adopted minimal. Feed of the spiral drill at finished machining of the holes with the diameter of $1-10 \mathrm{~mm}$ does not change. Feed of the carbide-tipped center and spiral drills is recommended to increase in 5 times, in

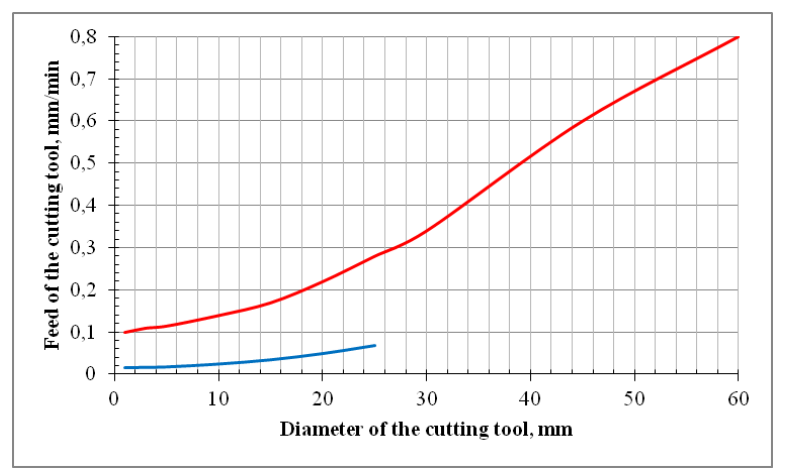

a)

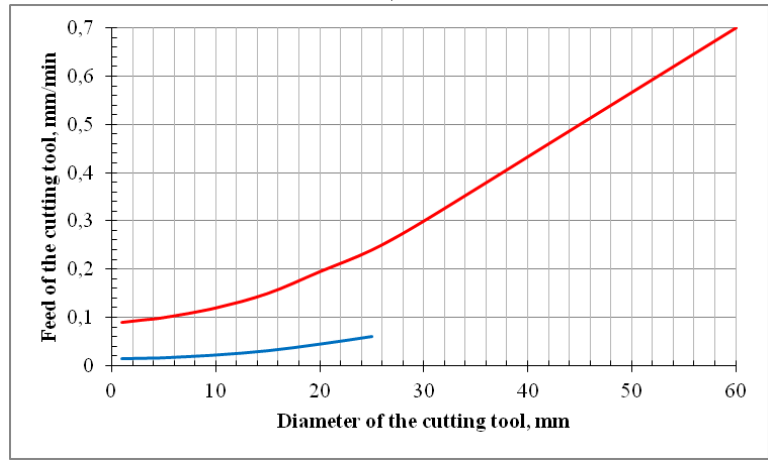

c) comparison with the axial cutting tools which are made from high-speed steel. Finished core drilling of the holes with the diameter of $6-40 \mathrm{~mm}$ is carried out at feed of the cutting tool $0.2-0.7 \mathrm{~mm} / \mathrm{min}$. A finished calibration of the holes by the reamer with the diameter of $20-40 \mathrm{~mm}$ can be performed at large feeds.

Feed value at milling by the end milling cutter, the face milling cutter, the radial milling cutter, the T-slot milling cutter and the conical milling cutter is presented on the dependencies graphs (Fig. 4).

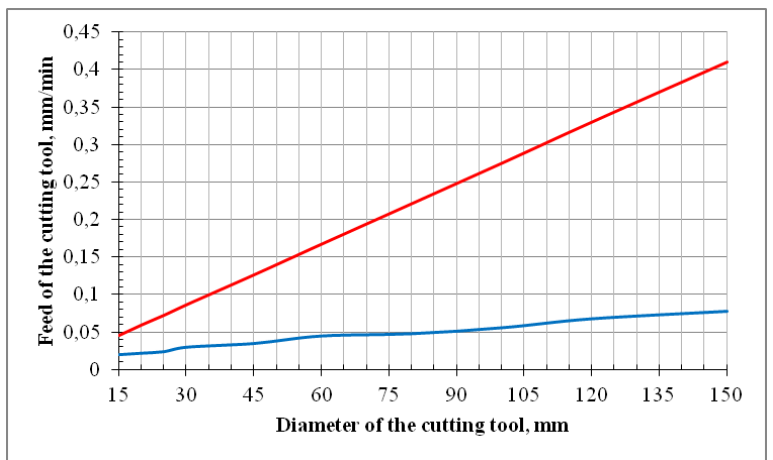

b)

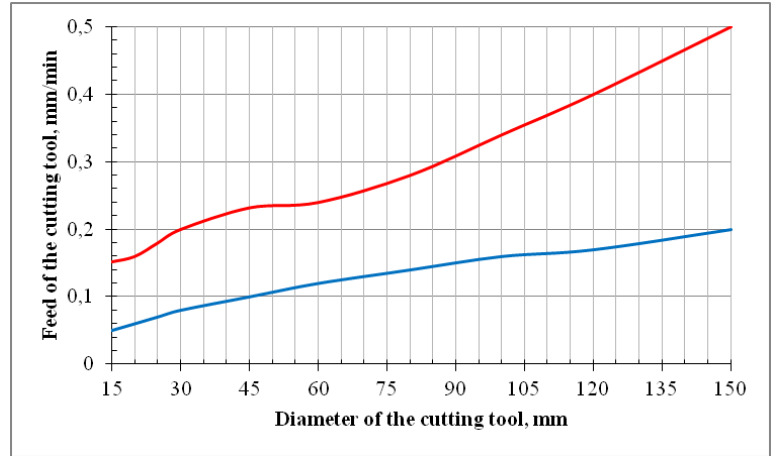

d)

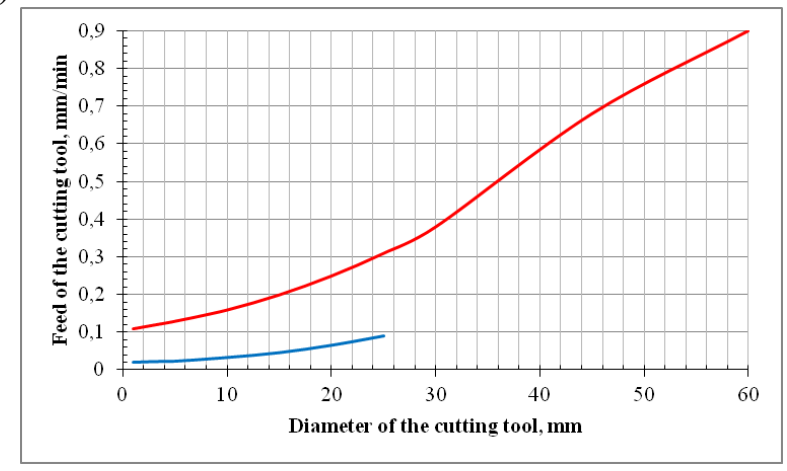

e)

Figure 4 - The dependencies of feed of the milling cutters from their diameters: a) — the end milling cutter made from high-speed steel (the one-piece tool), — the carbide-tipped end milling cutter (mechanically clamped); b) — the face milling cutter made from high-speed steel (the one-piece tool), — the carbide-tipped face milling cutter (mechanically clamped); c) — the radial milling cutter made from high-speed steel (the one-piece tool), — the carbide-tipped radial milling cutter (mechanically clamped); d) — the T-slot milling cutter made from high-speed steel (the one-piece tool), — the carbide-tipped T-slot milling cutter (mechanically clamped); e) — the conical milling cutter made from high-speed steel (the one-piece tool), the carbide-tipped conical milling cutter (mechanically clamped). 


\begin{tabular}{l|lr|ll|ll} 
& ISRA (India) & $=\mathbf{1 . 3 4 4}$ & SIS (USA) & $=\mathbf{0 . 9 1 2}$ & ICV (Poland) & $=\mathbf{6 . 6 3 0}$ \\
Impact Factor: & ISI (Dubai, UAE) $=\mathbf{0 . 8 2 9}$ & PUHЦ (Russia) $=\mathbf{0 . 2 0 7}$ & PIF (India) & $=\mathbf{1 . 9 4 0}$ \\
& GIF (Australia) & $\mathbf{0 . 5 6 4}$ & ESJI (KZ) & $=4.102$ & IBI (India) & $=\mathbf{4 . 2 6 0}$ \\
& JIF & $=\mathbf{1 . 5 0 0}$ & SJIF (Morocco) & $=\mathbf{2 . 0 3 1}$ & & \\
\hline
\end{tabular}

Decreasing of feed value of the milling cutter is associated with increasing of the diameter of the cutting tool. For the milling cutters made from highspeed steel with the diameter up to $60 \mathrm{~mm}$, feed at finished milling is set not more than $0.1 \mathrm{~mm} / \mathrm{min}$. For the carbide-tipped end milling cutter, radial milling cutter and conical milling cutter, feed at finished milling can set in the range of $0.1-0.9 \mathrm{~mm} / \mathrm{min}$. The least productivity is observed at milling of the steel workpieces by the carbide-tipped face milling cutter.

\section{Conclusion}

1. Turning by the round insert made from cemented carbide allows to increase productivity of the workpiece machining by $15-20 \%$. Thus, using of this insert is rational for finished steps of the turning process of the steel workpieces on the automated equipment in the conditions of serial and mass productions.

2. With increasing of the diameter of the processed cylindrical hole it is possible increasing of feed of the drill. Finished machining of the holes by the core drill and the reamer is recommended to perform at large feeds due to small cutting depth.

3. Milling by the conical milling cutter is performed with higher productivity in comparison with other types of the milling cutters. At milling by the face milling cutter and the T-slot milling cutter it is possible to reduce feed in $4-5$ times.

\section{References:}

1. (1980) GOST 19042-80. Throw-away (indexable) inserts. Classification. Notation. Forms.

2. (1985) GOST 26613-85. Lathe tools with mechanically clamped changeable indexable inserts. Specifications.

3. (2014) GOST 26595-2014 (ISO 6462:2011). Face milling cutters with mechanically clamped indexable inserts. Basic dimensions.

4. (2013) GOST 3855-2013. Milling cutters. Terms and definitions.
5. (1988) GOST 27724-88. Drills with mechanically clamped indexable inserts. Specifications.

6. (1977) GOST 10903-77. Twist drills with taper shanks. Basic dimensions.

7. (1993) GOST 18097-93. Screw-cutting lathes and lathes. Basic dimensions. Standards of accuracy.

8. (1988) GOST 17734-88. Knee-type millers. Standards of accuracy and rigidity. 